\title{
BIBLIOGRAPHIES
}

\author{
WALT WHITMAN: \\ A Bibliographical Checklist
}

WILLIAM WHITE

There is no up-to-date descriptive bibliography of Walt Whitman. This bibliographical checklist is not meant to supply that need, for it follows, with some variation, the format of First Printings of American Authors: Contributions Toward Descriptive Checklists, edited by Matthew J. Bruccoli and C.E. Frazer Clark, Jr. (Detroit: Gale Research Company, 1977), in which there is no entry for Whitman. The list below is of the first printings of Whitman's books, with a few "secondary" books in which Whitman material appears, and the two important collected editions of Whitman's writings. The list of references includes those books of a bibliographical nature dealing with Whitman, the most important of which, by Frank Shay, and by Carolyn Wells and Alfred F. Goldsmith, are long out of date; and the most recent, by Scott Giantvalley and by Donald D. Kummings, are concerned with books and articles about Whitman.

Although periodical matter is outside of the scope of this present list, attention might be brought to two publications of mine: Walt Whitman's fournalism: A Bibliography (Detroit: Wayne State University Press, 1969) and "Walt Whitman's Poetry in Periodicals: A Bibliography," The Serif, 11 (Summer 1974), 31-38. Eventually, The Collected Writings of Walt Whitman, of which 22 volumes have so far been published by the New York University Press, will contain a full-dress Whitman bibliography-but that is several years away, owing in part to the enormous bibliographical problems brought on by Whitman as an unorthodox self-publisher.

Meanwhile, Walt Whitman: A Bibliographical Checklist, while not complete, may be of some help to collectors, librarians, and Whitman specialists who may wish to know more about the first printings of his books.

1

FRANKLIN EVANS, OR THE INEBRIATE. A TALE OF THE TIMES. BY A POPULAR AMERICAN AUTHOR.

New York: J. Winchester, 1842.

Wrappers.

The author's name, "By Walter Whitman," appears in the original version in The

New World, Vol. II, No. 10, Extra Series, November 1842, pp. 1-31. Another version, "Copyright Edition," is entitled THE MERCHANT'S CLERK, IN NEW YORK; OR THE CAREER OF A YOUNG MAN FROM THE COUNTRY. BY WALTER WHITMAN.

LEAVES OF GRASS.

Brooklyn, New York, 1855. 
The earliest binding is blind-stamped green cloth; title in gilt in rustic letters, with triple line borders, on front and back covers; gilt title and ornaments on spine; all edges gilt; marbled end papers; frontispiece portrait printed on heavy white paper. Author's name only on verso of title page (in copyright notice) and on p. 29. Of this edition there are 10 variants, all in binding, end papers, illustration (frontispiece), amount of gilt, advertisements (press notices following the text). No textual variations in the 12 untitled poems.

\section{LEAVES OF GRASS.}

Brooklyn, New York, 1856.

Second edition, smaller format, with 20 additional poems; in gilt (under title and author) on spine: "I greet you at the beginning of a great career R. W. Emerson."

\section{4}

LEAVES OF GRASS IMPRINTS. AMERICAN AND EUROPEAN CRITICISMS ON "LEAVES OF GRASS."

Boston: Thayer and Eldridge, 1860.

Reviews by Whitman himself, pp. 7, 30, 38 .

\section{LEAVES OF GRASS.}

Boston: Thayer and Eldridge, Year 85 of The States. (1860-61).

Third edition, different format, with 122 additional poems (157 in all).

The earliest version may be identified by the frontispiece portrait on irregular tinted background, and by the gilt embossed butterfly on the backstrip; also the earliest binding is in orange cloth, with heavy embossing in wavy vertical lines. Also advance copies in brown wrappers.

WALT WHITMAN'S DRUM TAPS.

New-York, 1865.

The first version, identified by very thin fly-leaves and plain edges, lacks the "Sequel." This was later bound in, following p. [74], with its own title page: SEQUEL TO DRUM TAPS (SINCE THE PRECEDING CAME FROM THE PRESS) WHEN LILACS LAST IN THE DOOR-YARD BLOOM'D. AND OTHER PIECES.

Washington, 1865-6.

London: Chatto \& Windus, 1915.

New edition.

LEAVES OF GRASS.

New-York, 1867.

Fourth edition, completely revised, containing 150 poems.

The earliest binding was in half black morocco, with title in gilt on spine, and marbled end-papers. Second version adds "Drum-Taps" and "Sequel to DrumTaps" bound in, each with its own title page and pagination; these two have marbled end-papers and "Ed'n, 1867" in gilt at foot of spine. Third version has 
"Leaves of Grass" and "Songs Before Parting," each with its own title page and pagination; yellow end-papers. Fourth version has "Leaves of Grass," "DrumTaps," "Sequel to Drum-Taps," and "Songs Before Parting," in wrappers. All versions are dated 1867.

POEMS BY WALT WHITMAN.

London: John Camden Hotten, Picadilly, 1868.

Selected and edited by William Michael Rossetti.

MEMORANDA. DEMOCRATIC VISTAS.

Washington, D. C., 1871.

Pale green stiff wrappers, with line on front cover: "New-York: J. S. Redfield, Publisher, 140 Fulton St., (up stairs.)."

LEAVES OF GRASS. PASSAGE TO INDIA.

Washington, D. C., 1871.

Light green wrappers.

\section{LEAVES OF GRASS.}

Washington, D. C., 1871.

Fifth edition, copyright 1870, revised, with 28 new poems, 249 in all.

Light green wrappers, with line on front cover: "New-York: J. S. Redfield, Publisher, 140 Fulton St., (up stairs.)."

Later version, dated 1872, in green cloth, has "Passage to India" bound in with its own title page, table of contents, and pagination. Third version, in green cloth, also includes "After All, Not to Create Only," with its own title page, and "Complete" in gilt at the bottom of the spine. Fourth version, copyright 1876, in half cream-colored calf, marbled board sides, brown leather label, contains "Leaves of Grass" only, with a new title page consisting of the title and "Camden, New Jersey: Author's Edition, With Portraits from life, and Intercalations, 1876." At the top of the spine is, in gilt: "Centennial Ed'n-1876". A slip, listing the four intercalated poems, is pasted on the table of contents pages, and the poems are pasted on their respective pages in the book. ("Passage to India" and "After All, Not to Create Only" are included in a second volume of the Centennial Edition, entitled "Two Rivulets"-see below.) Fifth version drops "and Intercalation" from the title page, drops the pasted slips from the contents pages and from the book, and this material - the list and the four poems themselves-have now been set in type and new plates made for these pages.

AFTER ALL, NOT TO CREATE ONLY. RECITED BY WALT WHITMAN ON INVITATION OF MANAGERS AMERICAN INSTITUTE, ON OPENING THEIR 40TH ANNUAL EXHIBITION, NEW YORK, NOON, SEPTEMBER 7, 1871.

Boston: Robert Brothers, 1871.

Beveled maroon cloth; variants bound in brown limp cloth. 
AS A STRONG BIRD ON PINIONS FREE. AND OTHER POEMS.

Washington, D. C., 1872.

Dark green cloth.

"Leaves of Grass" in small type above title on title page.

14

MEMORANDA DURING THE WAR. BY WALT WHITMAN. AUTHOR'S PUBLICATION.

Camden, New Jersey, 1875-'76.

Maroon cloth.

Most copies autographed and inscribed by Whitman on preliminary "Remembrance Page"; some have autograph correction, "witless" for "written," p. 47, 1. 14 .

TWO RIVULETS INCLUDING DEMOCRATIC VISTAS, CENTENNIAL SONGS, AND PASSAGE TO INDIA.

Camden, New Jersey, 1876.

Copyright 1875, this was issued as Volume 2 with "Leaves of Grass" and called "Author's Edition" on the title page, dated 1876, with "Centennial Ed'n" in gilt on spine; binding similar to fifth edition, fourth version of "Leaves of Grass."

LEAVES OF GRASS.

Boston: James R. Osgood \& Company, 1881-82.

Sixth edition, copyright 1881 , completely revised, 317 poems in all.

First printing has "Third Edition" on title page in error.

Author's name in gilt on front cover, and in the text only on the verso of the title page (copyright notice) and on p. 48 in the beginning line of "Song of Myself," Section 24, "Walt Whitman, a kosmos, of Manhattan the son." The earliest binding was yellow cloth, with the top edge plain. After the book was withdrawn by Osgood from publication, Whitman bought the plates, changed the imprint on the title page to read "Author's edition Camden, New Jersey, 1882."; the binding is dark green, the top edge gilt, and the spine reads "Author's Edition Leaves of Grass Complete Autograph and Portraits 1882." The next version has "Philadelphia: Rees Welsh \& Co., No. 23 South Ninth Street, 1882" on the title page, and "Rees Welsh \& Co." in gilt on the spine; the binding is dull yellow. Another printing has "Philadelphia: David McKay, 1884" on title page and "Putnam" on spine, or "Philadelphia 1884," or blank. The fourth version substitutes "David McKay" for "Rees Welsh \& Co." on both the title page and spine. The fifth version, on large paper, which reads on the title page, "Complete Poems \& Prose, 1855 . . . 1888 Authenticated \& Personal Book (Handled by W. W.) . . . Portraits from Life . . . Autograph", is made up of the 1881 "Leaves of Grass," plus "Specimen Days \& Collect" (see below), some new poems from "November Boughs" (see below), and two new brief items, "Note at Beginning" and "Note at End," dated "W. W., Nov. 13, '88." The sixth version (1889) reads on the title page: "Leaves of Grass with Sands at Seventy \& A Backward Glance o'er Travel'd Roads". These two annexes are added, with the latter having its separate pagina- 
tion. The seventh version, with the imprint on the title page, "Philadelphia: David McKay, 1891-92," often called the Deathbed Edition, adds the following to the 1881 "Leaves of Grass": "Sands at Seventy . . . 1st Annex," "Good-Bye My Fancy ... 2d Annex" (see below), "A Backward Glance o'er Travel'd Roads," and Portrait from Life. The eighth version, with the imprint on the title page, "Boston: Small, Maynard \& Co., 1897," adds to the previous version, the posthumous "Old Age Echoes."

LEAVES OF GRASS BY WALT WHITMAN.

London: David Bogue, 1881.

Line on title page reads: "Author's copyright edition." Printed from sheets of the Osgood edition with a new title page.

Bound in green cloth.

London: Wilson \& McCormick, 1884.

Printed from sheets of the Osgood edition with a new title page.

18

LEAVES OF GRASS BY WALT WHITMAN: PREFACE TO THE ORIGINAL EDITION, 1855.

London: Trubner \& Co., 1881.

Pale green wrappers, limited to 500 copies, plus a large-paper printing of 25 copies in light blue wrappers.

SPECIMEN DAYS \& COLLECT BY WALT WHITMAN.

Philadelphia: Rees Welsh \& Co., 1882-'83.

Copyright 1882. Also a large-paper edition.

New version, with title "Complete Prose Works," Philadelphia: David McKay, 1892 (copyright 1891) adds "November Boughs" and "Good-Bye My Fancy." Advance (trial) copy of the David McKay printing (1888) in wrappers includes "November Boughs."

Glasgow: Wilson \& McCormick, 1883.

Printed from Rees Welsh sheets.

SPECIMEN DAYS IN AMERICA BY WALT WHITMAN.

London: Walter Scott, 1887.

Lines on title page read: "Newly revised by the author, with fresh preface / and additional note."

Variant bindings: half-leather, and blue cloth (both in Camelot Series).

NOVEMBER BOUGHS.

Philadelphia: David McKay, 1888.

The earliest version, for presentation, was bound in limp maroon cloth, uncut, with "Walt Whitman's November Boughs" in gilt on front cover. Later bindings in maroon cloth, and in green cloth, with gilt top edge and different lettering on spine. 
Paisley and London: Alexander Gardner, 1889.

Printed from David McKay sheets with a new title page.

DEMOCRATIC VISTAS, AND OTHER PAPERS BY WALT WHITMAN.

London: Walter Scott, 1888.

Variant bindings: Blue cloth (Camelot Series), and green cloth (The Scott Library); advertisements in back vary.

GEMS FROM WALT WHITMAN, ed. Elizabeth Porter Gould.

Philadelphia: David McKay, 1889.

GOOD-BYE MY FANCY 2D ANNEX TO LEAVES OF GRASS.

Philadelphia: David McKay, 1891.

Author's name in gilt on front cover.

Advance copy in wrappers.

AUTOBIOGRAPHIA OR THE STORY OF A LIFE BY WALT WHITMAN SELECTED FROM HIS PROSE WRITINGS, ed. Arthur Stedman.

New York: Charles L. Webster \& Co., 1892.

In Fiction, Fact, and Fancy Series.

London: G. P. Putnam's Sons, 1892.

SELECTED POEMS BY WALT WHITMAN, ed. Arthur Stedman.

New York: Charles L. Webster \& Co., 1892.

In Fiction, Fact, and Fancy Series.

IN RE WALT WHITMAN, ed. Horace L. Traubel, Richard Maurice Bucke, and Thomas B. Harned.

Philadelphia: David McKay, 1893.

Limited to 1,000 copies, numbered.

28

CALAMUS: A SERIES OF LETTERS WRITTEN DURING THE YEARS 1868-1880 BY WALT WHITMAN TO A YOUNG FRIEND (PETER DOYLE), ed. Richard Maurice Bucke, M. D.

Boston: Laurens Maynard, MDCCCXCVII.

Limited to 35 large-paper numbered copies (of which 25 are for sale), signed by Bucke, followed by a regular edition. Copyright 1897.

29

THE WOUND DRESSER A SERIES OF LETTERS WRITTEN FROM THE HOSPITALS IN WASHINGTON DURING THE WAR OF THE REBELLION BY WALT WHITMAN, ed. Richard Maurice Bucke, $M$. D.

Boston: Small, Maynard \& Company, 1898.

Limited to 60 large-paper numbered copies (of which 50 are for sale), signed by Bucke. Earliest copies of the trade edition have the publisher's device on the title page slightly off center. Copyright 1897. 
WALT WHITMAN AT HOME, by Himself.

New York: The Critic Company, 1898.

Critic Pamphlet No. 2. Reprint of "Walt Whitman in Camden," by George Selwyn (Walt Whitman), The Critic, 28 February 1885.

NOTES AND FRAGMENTS: LEFT BY WALT WHITMAN, ed. Dr. Richard Maurice Bucke.

Printed for Private Distribution Only, 1899.

Limited to 225 copies, numbered and signed by the editor.

32

LEAVES OF GRASS BY WALT WHITMAN INCLUDING A FACSIMILE AUTOBIOGRAPHY, VARIORUM HEADINGS OF THE POEMS AND A DEPARTMENT OF GATHERED LEAVES.

Philadelphia: David McKay, 1900.

This is the first attempt at a variorum edition. Preface by David McKay.

33

LETTERS WRITTEN BY WALT WHITMAN TO HIS MOTHER FROM 1866 TO 1872 TOGETHER WITH CERTAIN PAPERS PREPARED FROM MATERIAL NOW FIRST UTILIZED, ed. Thomas B. Harned.

New York and London: G. P. Putnam's Sons, 1902.

Limited to 5 copies.

Reprinted in a new edition, with an Introduction by Rollo G. Silver, 325 copies, New York: A. F. Goldsmith, at the Sign of the Sparrow, 1936.

34

AN AMERICAN PRIMER BY WALT WHITMAN WITH FACSIMILES OF THE ORIGINAL MANUSCRIPT, ed. Horace Traubel.

Boston: Small, Maynard \& Company, MCMIV.

Limited to 500 copies.

35

WALT WHITMAN'S DIARY IN CANADA WITH EXTRACTS FROM OTHER OF HIS DIARIES AND LITERARY NOTE-BOOKS, ed. William Sloane Kennedy.

Boston: Small, Maynard \& Company, MCMIV.

Limited to 500 copies.

36

LAFAYETTE IN BROOKLYN BY WALT WHITMAN, intro. John Burroughs. New York: George D. Smith, 1905.

Limited to 250 copies, signed by the publisher, 15 of which are on Imperial Japanese Vellum and 25 on American Hand-Made paper. Slip with title and author on front cover have date 1904; date on title page and verso (copyright) is 1905.

THE BOOK OF HEAVENLY DEATH BY WALT WHITMAN COMPILED FROM LEAVES OF GRASS, ed. Horace Traubel. 
Portland, Me.: Thomas B. Mosher, MDCCCCV.

Limited to 500 copies on Van Gelder hand-made paper and 50 copies on Japanese vellum.

38

CRITICISM AN ESSAY BY WALT WHITMAN.

Newark, N. J.: Carteret Book Club, 1913.

Limited by 100 copies, numbered, on Italian handmade paper. Boxed.

Reprinted as a Troutbeck Leaflet, No. 2, Amenia, N.Y.: Troutbeck Press, 1924, 200 copies, as a "Christmas greeting to the friends of Amy E. and J. E. Spingarn."

THE LETTERS OF ANNE GILCHRIST AND WALT WHITMAN, ed. Thomas B. Harned.

Garden City, New York: Doubleday, Page \& Company, 1918.

40

THE GATHERING OF THE FORCES BY WALT WHITMAN EDITORIALS, ESSAYS, LITERARY AND DRAMATIC REVIEWS AND OTHER MATERIAL WRITTEN BY WALT WHITMAN AS EDITOR OF THE BROOKLYN DAILY EAGLE IN 1846 AND 1847, ed. Cleveland Rodgers and John Black. 2 vols.

New York and London: G. P. Putnam's Sons, 1920.

Limited letterpress edition, printed from type, 1250 sets.

41

THE UNCOLLECTED POETRY AND PROSE OF WALT WHITMAN MUCH OF WHICH HAS BEEN BUT RECENTLY DISCOVERED WITH VARIOUS EARLY MANUSCRIPTS NOW FIRST PUBLISHED, ed. Emory Holloway. 2 vols.

Garden City, N. Y., and Toronto: Doubleday, Page \& Company, 1921.

Copyright page: "First edition."

INCLUSIVE EDITION LEAVES OF GRASS BY WALT WHITMAN FROM THE TEXT OF THE EDITION AUTHORIZED AND EDITORIALLY SUPERVISED BY HIS LITERARY EXECUTORS, RICHARD MAURICE BUCKE, THOMAS B. HARNED, AND HORACE L. TRAUBEL, ed. Emory Holloway.

Garden City, New York: Doubleday, Page \& Company, 1924.

Advance copies uncut and in boards. Regular edition in cloth and limp leather.

PICTURES AN UNPUBLISHED POEM OF WALT WHITMAN, ed. Emory Holloway.

New York: The June House; London: Faber \& Guyer, Ltd., 1927.

Limited to 700 copies, 350 to be sold in the United States and 350 in England, 25 signed by Henry Goldsmith.

THE HALF-BREED AND OTHER STORIES BY WALT WHITMAN NOW FIRST COLLECTED, ed. Thomas Ollive Mabbott. 
New York: Columbia University Press, 1927.

Half-title and front cover: Short Stories by Walt Whitman.

Limited to 155 copies; the first 30 have "illustrations ... proofs pulled direct from wood blocks and signed by the artist [Allen Lewis]."

45

THE EIGHTEENTH PRESIDENCY! VOICE OF WALT WHITMAN TO EACH YOUNG MAN IN THE NATION, NORTH, SOUTH, EAST, AND WEST, ed. Jean Catel.

Paris: Edition "Tambour," [1928].

Wrappers. City and publisher are on a slip pasted on title page.

RIVULETS OF PROSE CRITICAL ESSAYS BY WALT WHITMAN, ed. Carolyn Wells and Alfred F. Goldsmith.

New York: Greenberg, MCMXXVIII.

Limited to 499 copies, boxed.

Of the 21 pieces, three are in book form for the first time: "Boz and Democracy," "Poetry of the Future," and "A Perfect School."

47

WALT WHITMAN'S WORKSHOP. A COLLECTION OF UNPUBLISHED MANUSCRIPTS, ed. Clifton Joseph Furness.

Cambridge: Harvard University Press, 1928.

Limited to 750 copies, boxed.

A CHILD'S REMINISCENCE BY WALT WHITMAN, ed. Thomas O. Mabbott and Rollo G. Silver.

Seattle: University of Washington Book Store, 1930.

Limited to 475 copies.

49

I SIT AND LOOK OUT EDITORIALS FROM THE BROOKLYN DAILY TIMES BY WALT WHITMAN, ed. Emory Holloway and Vernolian Schwarz.

New York: Columbia University Press, MCMXXXII.

Limited to 1,000 copies.

50

WALT WHITMAN AND THE CIVIL WAR A COLLECTION OF ORIGINAL ARTICLES AND MANUSCRIPTS, ed. Charles I. Glicksberg.

Philadelphia: University of Pennsylvania Press, 1933.

51

NEW YORK DISSECTED BY WALT WHITMAN A SHEAF OF RECENTLY DISCOVERED NEWSPAPER ARTICLES BY THE AUTHOR OF LEAVES

OF GRASS, ed. Emory Holloway and Ralph Adimari.

New York: Rufus Rockwell Wilson, Inc., 1936.

"This, the first edition . . . is limited to 750 numbered copies." 
WALT WHITMAN'S BACKWARD GLANCES A BACKWARD GLANCE O'ER TRAVEL'D ROADS AND TWO CONTRIBUTORY ESSAYS HITHERTO UNCOLLECTED, ed. Sculley Bradley and John A. Stevenson.

Philadelphia: University of Pennsylvania Press, 1947.

52

FAINT CLEWS \& INDIRECTIONS MANUSCRIPTS OF WALT WHITMAN AND HIS FAMILY, ed. Clarence Gohdes and Rollo G. Silver.

Durham, N. C.: Duke University Press, MCMXLIX.

54

A WHITMAN MANUSCRIPT FROM THE ALFRED M. BENDER COLLECTION OF MILLS COLLEGE.

[Oakland, California] The Bibliophile Society of Mills College, 1939.

Limited to 175 copies.

WALT WHITMAN OF THE NEW YORK AURORA EDITOR AT TWENTY-TWO A COLLECTION OF RECENTLY DISCOVERED WRITINGS, ed. Joseph Jay Rubin and Charles H. Brown.

State College, Penns.: Bald Eagle Press, 1950.

WALT WHITMAN LOOKS AT THE SCHOOLS, ed. Florence Bernstein Freedman.

New York: King's Crown Press, Columbia University, 1950.

Articles from the Brooklyn Evening Star and the Brooklyn Daily Eagle.

57

WHITMAN'S MANUSCRIPTS LEAVES OF GRASS (1860) A PARALLEL TEXT, ed. Fredson Bowers.

Chicago: The University of Chicago Press, [1955].

58

WALT WHITMAN AN 1855-1856 NOTEBOOK TOWARD THE SECOND EDITION OF LEAVES OF GRASS, ed. Harold W. Blodgett and William White.

Carbondale: Southern Illinois University Press, [1959].

Limited to 500 copies, plus 50 copies on Arches paper, including original Whitman memorabilia.

59

THE PEOPLE AND JOHN QUINCY ADAMS BY WALT WHITMAN, ed. William White.

Berkeley Heights, N. J.: The Oriole Press, 1961.

Limited to 100 copies.

Wrappers.

60

WALT WHITMAN'S BLUE BOOK THE 1860-61 LEAVES OF GRASS CONTAINING HIS MANUSCRIPT ADDITIONS AND REVISIONS, ed. Arthur Golden. 2 vols.

New York: The New York Public Library, 1968.

Boxed. 
WALT WHITMAN'S AUTOGRAPH REVISION OF THE ANALYSIS OF LEAVES OF GRASS (FOR DR. R. M. BUCKE'S WALT WHITMAN), intro. Quentin Anderson, ed. Stephen Railton.

New York: New York University Press, 1974.

WALT WHITMAN: COMPLETE POETRY AND COLLECTED PROSE, ed. Justin Kaplan.

[New York]: The Library of America, [1982]. Trade edn., The Viking Press.

Contains: Leaves of Grass (1855), Leaves of Grass (1891-92), Complete Prose Works (1892), Supplementary Prose.

Included here as perhaps the best one-volume edition of poetry and prose.

\section{SECONDARY}

\section{3}

James J. Brenton, ed. VOICES FROM THE PRESS: A COLLECTION OF SKETCHES, ESSAYS, AND POEMS, BY PRACTICAL PRINTERS.

New York: Charles B. Norton, 1850.

Contains "The Tomb Blossoms," by Walter Whitman. Copyright 1849.

64

William Douglas O'Connor, THE GOOD GRAY POET. A VINDICATION.

New York: Bunce and Huntington, 1866.

"Edited" by Whitman.

John Burroughs, NOTES ON WALT WHITMAN AS POET AND PERSON. New York: American News Company, 1867.

Partly written by Whitman.

66

THE POETS' TRIBUTES TO GARFIELD THE COLLECTION OF POEMS WRITTEN FOR THE BOSTON DAILY GLOBE, AND MANY SELECTIONS WITH PORTRAIT AND BIOGRAPHY.

Cambridge: Moses King, 1881.

Contains "The Sobbing of the Bells. (Midnight, September 19-20.)" by Walt Whitman.

\section{7}

ESSAYS FROM "THE CRITIC." BY JOHN BURROUGHS, EDMUND C. STEDMAN, WALT WHITMAN, R. H. STODDARD, F. B. SANBORN, AND OTHERS.

Boston: James R. Osgood and Company, 1882.

Contains "Death of Carlyle" and "Death of Longfellow."

68

Richard Maurice Bucke, M. D., WALT WHITMAN.

Philadelphia: David McKay, 1883.

Edited and partially written by Whitman. 
Some copies have imprint: Published for the Author.

Glasgow: Wilson \& McCormick, 1883.

CAMDEN'S COMPLIMENT TO WALT WHITMAN, MAY 31, 1889 NOTES, ADDRESSES, LETTERS, TELEGRAMS, ed. Horace L. Traubel.

Philadelphia: David McKay, 1889.

Contains Autobiographic Note from an old "remembrance copy," by Walt Whitman.

70

J. Johnston, M. D., NOTES OF A VISIT TO WALT WHITMAN, ETC., IN JULY, 1890.

Bolton: T. Brimslow \& Co., Printers, \&c., 1890.

Contains letters, extracts, poems, conversations of Whitman.

Wrappers.

Printed for private circulation.

71

David G. Brinton and Thomas Davidson, GIORDANO BRUNO: PHILOSOPHER AND MARTYR. TWO ADDRESSES.

Philadelphia: David McKay, 1890.

Contains Forward by Walt Whitman.

72

William Douglas O'Connor, THREE TALES THE GHOST THE BRAZEN ANDROID THE CARPENTER.

Boston and New York: Houghton, Mifflin and Company, 1892.

Copyright 1891.

Contains Preface by Walt Whitman. Character of the Carpenter based on Whitman.

73

John Addington Symonds, WALT WHITMAN A STUDY.

London: John C. Nimmo, MDCCCXCIII.

Large paper edition limited to 208 numbered copies on Arnold's unbleached handmade paper.

74

Sadakichi [Hartmann], CONVERSATIONS WITH WALT WHITMAN. WRITTEN IN 1894.

New York: E. P. Coby and Co., 1895.

Untrustworthy.

75

William Sloane Kennedy, REMINISCENCES OF WALT WHITMAN WITH EXTRACTS FROM HIS LETTERS AND REMARKS ON HIS WRITINGS. Philadelphia: David McKay, 1896.

Paisley and London: Alexander Gardner, 1896. 
Thomas B. Donaldson, WALT WHITMAN THE MAN.

New York: Francis P. Harper, 1896.

Contains nine facsimiles.

London: Suckling \& Galloway, 1896.

John Johnston, M. D., DIARY NOTES OF A VISIT TO WALT WHITMAN AND SOME OF HIS FRIENDS, IN 1890.

Manchester: The Labour Press Limited; London: The "Clarion" Office, 1898.

CATALOGUE OF A COLLECTION OF BOOKS, LETTERS AND MANUSCRIPTS BY WALT WHITMAN IN THE LIBRARY OF GEORGE M. WILLIAMSON.

Jamaica, Long Island: The Marion Press, [1903].

Limited to 25 copies on Japanese paper, 102 copies on plated paper.

Horace Traubel, WITH WALT WHITMAN IN CAMDEN. 6 vols.

Vol. 1, Boston: Small, Maynard \& Company, 1906; Vol. 2, New York: D. Appleton and Co., 1908; Vol. 3, New York: Mitchell Kennerley, 1914; Vol. 4, ed. Sculley Bradley, Philadelphia: University of Pennsylvania Press, [1953]; Vol. 5, ed. Gertrude Traubel, Carbondale: Southern Illinois University Press, [1964]; Vol. 6, ed. Gertrude Traubel and William White, Carbondale: Southern Illinois University Press, [1982].

Contains letters, conversations, excerpts by Whitman.

80

Charles N. Elliot, ed., WALT WHITMAN AS MAN, POET AND FRIEND BEING AUTOGRAPH PAGES FROM MANY PENS.

Boston: Richard G. Badger, [1915].

Contains post card to Peter Doyle, 26 February [187?].

81

J[ohn] Johnston, M. D., and J. W. Wallace, VISITS TO WALT WHITMAN IN 1890-1891 BY TWO LANCASHIRE FRIENDS.

London: George Allen \& Unwin Ltd., [1917].

Copyright page: First published in December 1917.

82

Katherine Molinoff, ed., AN UNPUBLISHED WHITMAN MANUSCRIPT THE RECORD BOOK OF THE SMITHTOWN DEBATING SOCIETY 18371838.

[Brooklyn: Comet Press, 1941.]

Monograph No. 1 on Unpublished Whitman Material; No. 2, "Some Notes on Whitman's Family [letter to Mary, 28 November 1890]" and "Walt Whitman in Vermont." 
Horst Frenz, ed., WHITMAN AND ROLLESTON A CORRESPONDENCE. Bloomington: Indiana University Publications, 1951.

Contains seven letters from Whitman to Rolleston.

Dublin: Browne and Nolan, Limited, The Richview Press. [1952].

84

Walter Lowenfels, ed., WALT WHITMAN'S CIVIL WAR COMPILED \& EDITED FROM PUBLISHED AND UNPUBLISHED SOURCES.

New York: Alfred A. Knopf, 1960.

Contains several prose passages (from MSS) and two poems "Return of the Heroes" and "There rises in my brain the thought of graves."

Thomas L. Brasher, WHITMAN AS EDITOR OF THE BROOKLYN DAILY EAGLE.

Detroit: Wayne State University Press, 1970.

Contains numerous editorials from the Brooklyn Daily Eagle.

86

Joseph Jay Rubin, THE HISTORIC WHITMAN.

University Park and London: The Pennsylvania State University Press, [1973]. Contains "Letters from a Travelling Bachelor" from the New York Sunday Dispatch, 14 October 1849 to 6 January 1850.

87

Gloria A. Francis and Artem Lozynsky, WHITMAN AT AUCTION 1899-1972, intro. Charles E. Feinberg.

Detroit: A Bruccoli Clark Book, Gale Research Company, [1978].

\section{COLLECTIONS}

88

THE COMPLETE WRITINGS OF WALT WHITMAN ISSUED UNDER THE EDITORIAL SUPERVISION OF HIS LITERARY EXECUTORS, RICHARD MAURICE BUCKE, THOMAS B. HARNED, AND HORACE TRAUBEL WITH ADDITIONAL BIBLIOGRAPHICAL AND CRITICAL MATERIAL PREPARED BY OSCAR LOVELL TRIGGS, PH. D. 10 vols.

New York \& London: G. P. Putnam's Sons, The Knickerbocker Press, [1902]. Autograph edition, 32 sets; Paumanok edition, 300 sets; Camden edition, 300 sets-published simultaneously.

89

THE COLLECTED WRITINGS OF WALT WHITMAN, gen. eds. Gay Wilson Allen and Sculley Bradley.

THE CORRESPONDENCE, ed. Edwin Haviland Miller. 6 vols. 1961, 1961, 1964, 1969, 1969, 1977.

THE EARLY POEMS AND THE FICTION, ed. Thomas L. Brasher. 1963. PROSE WORKS 1892, ed. Floyd Stovall. 2 vols. 1963, 1964.

LEAVES OF GRASS: COMPREHENSIVE READER'S EDITION, ed. 
Harold W. Blodgett and Sculley Bradley. 1965. London: University of London Press, 1965.

DAYBOOKS AND NOTEBOOKS, ed. William White. 3 vols. 1978 (copyright 1977).

LEAVES OF GRASS: A TEXTUAL VARIORUM OF THE PRINTED POEMS, ed. Sculley Bradley, Harold W. Blodgett, Arthur Golden, and William White. 3 vols. 1980.

NOTEBOOKS AND UNPUBLISHED PROSE MANUSCRIPTS, ed. Edward F. Grier. 6 vols. 1984.

New York: New York University Press, 1961-1984.

\section{REFERENCES}

Frank Shay. The Bibliography of Walt Whitman.

New York: Friedmans', 1920.

Carolyn Wells and Alfred F. Goldsmith. A Concise Bibliography of the Works of Walt Whitman With a Supplement of Fifty Books About Whitman.

Boston and New York: Houghton Mifflin Company, MDCCCXXII.

92

William Sloane Kennedy. The Fight of a Book for the World: A Companion Volume to Leaves of Grass.

West Yarmouth, Mass.: The Stonecroft Press, 1926.

93

Ellen Frances Frey. Catalogue of the Whitman Collection in the Duke University Library Being a Part of the Trent Collection Given by Dr. and Mrs. Fosiah C. Trent. Durham, N. C.: Duke University Library, 1945.

94

Walt Whitman: The Oscar Lion Collection.

New York: The New York Public Library, 1953.

95

Walt Whitman: Catalogue of an Exhibition Held at the American Library, London, March-April 1954.

London: United States Information Service, 1954.

[Frances E. Brewer.] Walt Whitman: A Selection of the Manuscripts, Books and Association Items Gathered by Charles E. Feinberg: Catalogue of an Exhibition Held at the Detroit Public Library, Detroit, Michigan, 1955.

[Detroit: Charles E. Feinberg, 1955.]

Lewis M. Stark and John D. Gordan. Walt Whitman's Leaves of Grass: $A$ Centenary Exhibition from the Lion Whitman Collection and the Berg Collection of the New York Public Library.

New York: The New York Public Library, 1955. 
Walt Whitman: A Catalog Based Upon the Collections of the Library of Congress With Notes on Whitman Collections and Collectors, [by Charles E. Feinberg]. Washington: Reference Department: The Library of Congress, 1955.

James T. F. Tanner. Walt Whitman: A Supplementary Bibliography, 1961-1967.

Kent, Ohio: The Kent State University Press, 1968.

100

William White. Walt Whitman's fournalism: A Bibliography.

Detroit: Wayne State University Press, 1969.

101

Gay Wilson Allen. The New Walt Whitman Handbook.

New York: New York University Press, 1975.

102

Jeanetta Boswell. Walt Whitman and the Critics: A Checklist of Criticism, 19001978.

Metuchen, N. J., \& London: The Scarecrow Press, Inc., 1980.

103

Scott Giantvalley. Walt Whitman, 1838-1939: A Reference Guide.

Boston: G. K. Hall \& Co., 1981.

104

Donald D. Kummings. Walt Whitman, 1940-1975: A Reference Guide.

Boston: G. K. Hall \& Co., 1982.

Oakland University 